\title{
RELIGION AND LAW IN $R \quad V$ NS: FINDING SPACE TO RE-THINK THE BALANCING ANALYSIS
}

\author{
Blair Major*
}

In this article, the author argues against the balancing approach used in the recent case of the Supreme Court of Canada R v NS (2012). It is argued that this approach inhibits critical reflection on the complex philosophical issues that underlie the decision, and that it closes itself off to meaningful engagement with diverse perspectives. These arguments are developed by reflecting on the idea of incommensurability and on Alasdair MacIntyre's theory of tradition. The author concludes that this analysis provides a starting point for developing an approach that has greater capacity for critical reflection and is more capable of embracing diversity.

L'auteur critique l'approche utilisée dans la récente décision de la Cour Suprême du Canada R c NS (2012), laquelle se fondait sur la recherche d'un équilibre entre la liberté de religion et l'équité du procès. Sa critique - fondée sur l'idée d'incommensurabilité et la théorie de tradition d'Alisdair MacIntyre - démontre que l'approche retenue par la Cour Suprême limite l'analyse critique de questions philosophiques complexes que soustendent la décision, et refuse d'aborder sérieusement des perspectives diverses. L'analyse de l'auteur offre un point de départ pour développer une approche dotée d'une plus grande capacité pour la réflexion critique et promet de mieux incorporer la diversité.

\section{INTRODUCTION}

At the end of 2012, the Supreme Court of Canada [SCC] handed down the decision $R v N S,{ }^{1}$ regarding a claim filed by the appellant, NS, alleging charges of sexual assault against her uncle and cousin. The reason why this case ended up before the SCC is that NS is a Muslim woman who wears a niqab, which covers her face, as part of her religious practice. At the preliminary inquiry hearing, the defendants succeeded in asking the Court to order NS to remove her niqab while she provided oral testimony. The basis of the claim was that her face should be visible in order to evaluate the veracity of her testimony, which is a matter of trial fairness. NS refused to comply with the order and appealed it, arguing that her religious beliefs precluded her from removing the niqab in the context of the trial (given the presence of men who were not family members). Through the process of appeals, the matter ended up going before the SCC, where the Court had to decide on what basis a judge presiding over a criminal trial should permit (or refuse) a female Muslim witness to wear a niqab while giving oral testimony.

\footnotetext{
* Doctor of Civil Law Candidate, McGill University, Faculty of Law. Supported by the Social Sciences and Humanities Research Council of Canada, Joseph-Armand Bombardier CGS Doctoral Scholarship.

12012 SCC 72, 353 DLR. (4th) 577, [2012] SCJ no 72 (QL) [NS].
} 
The NS case is primarily about how to resolve a conflict between two rights protected in the Charter - in this case, the right to religious freedom and the right to a fair trial. ${ }^{2}$ But upon closer examination there is much more at stake here. In order to resolve the conflict between the competing rights the Court draws upon a set of philosophical principles that provide a conceptual framework for navigating through the complexity of the claims involved. Tuning our ears to the issues and questions that arise regarding these foundational perspectives opens us to a wealth of new ideas and new perspectives on the workings of legal discourse and its interaction with diverse claims. This allows us to see the court's dealings with claims of religious freedom in a new light, and provides a remarkable opportunity to reflect on the structures that affect the relationship between legal discourse and religious ideas more generally.

I will argue that the analysis employed by the Court in NS does not engage the full range of issues at play in the case. The Court focuses on developing a balancing analysis but fails to meaningfully reflect on the 'conceptual framework' on which that analysis is based. What I would like to look at in the NS case are not the arguments regarding the substance of the right to religious freedom or to a fair trial, but the way that the Court navigates its decision between these two rights. This will help us identify some of the philosophical assumptions operating within the decision, and open the door to further questions regarding the framework of legal discourse.

Directly following the introductory discussion of the $N S$ case, I will look at the so-called incommensurability thesis to help clarify and sharpen some of the questions that arise regarding the balancing analysis. The incommensurability thesis, as articulated and developed by contemporary theorists, openly embraces the important role played by our social contexts in the formation of the conceptual frameworks used in legal decision-making. This leads us to some very difficult and complex philosophical questions regarding how we think about and engage with these frameworks. I conclude that the incommensurability thesis does not provide sufficient means to address these questions.

In the final section of the paper I suggest that it can be helpful to approach the issues left unaddressed by $N S$ and the incommensurability thesis from a perspective foreign to legal analysis. Doing so can help reframe the matter in a way that sheds new light on the problems we encounter and makes available novel solutions to the questions raised. I propose the theory of Alasdair MacIntyre, and its effect on rational enquiry, as providing a particularly helpful alternative perspective.

The orientation of MacIntyre's theory towards religious thought makes his ideas particularly interesting in the context of a discussion of the NS case. Although MacIntyre does not describe his theory as religious, he unapologetically recognizes his reliance on ideas that are deeply intertwined with Christian thought, developing his philosophical approach from the foundations of Thomistic philosophy. He has been described by some as a 'new Traditionalist' and listed alongside well-known contemporary theologians like Stanley Hauerwas. ${ }^{3}$ Because of this, using MacIntyre's theory to re-frame the issues encountered in $N S$ draws our attention to the (for some, uncomfortable) possibility that the key to resolving conflicts between rights might be found in the hands of the veiled woman of faith. Or, rather, that in order to resolve conflicts between rights we have to be able to use the keys in her hand together with those in our own.

2 Canadian Charter of Rights and Freedoms, ss 2(a), 11(d), Part I of the Constitution Act, 1982, being Schedule B to the Canada Act 1982 (UK), 1982, c 11 [the Charter].

3 See, e.g. Jeffrey Stout, Democracy and Tradition (Princeton: Princeton University Press, 2004). 
The central concern of this paper is about more than the resolution of conflicting rights. Likewise, it goes beyond the idea of religious freedom as a constitutionally protected right. It is geared instead towards the nature of legal discourse and the related complex philosophical questions that all too often fade into the background. The way in which legal discourse and legal analysis is framed deeply affects its relationship with the other voices and structured discourses that exist in society. This paper seeks to understand the nature of the interaction between these various voices within the context of legal analysis and to explore new ways to approach how the interaction is framed. This opens the door to further reflect on ways to integrate religious voices into the legal analysis and the process of legal discourse more generally. What I hope to accomplish here is to begin the process of thinking through these important issues, and to identify a new set of questions and ideas that will add to an ongoing conversation.

\section{R V NS AND THE BALANCING ANALYSIS}

The Supreme Court of Canada in NS adopts a balancing analysis for resolving the conflict of rights. Looking at this balancing analysis, and how it is applied, helps reveal important features of the conceptual framework that the Court relies on in making its decision. This framework shapes the way that the Court approaches many of the issues in the case. As we become aware of this, we can trace some of these effects. Unfortunately, the Court appears to turn a blind eye towards the philosophical commitments related to its conceptual framework, and the questions that these commitments raise. Looking closely at the way that the balancing test is applied will help uncover the philosophical complexity operating under the surface of the decision, which also opens space to consider some alternative ways for thinking about the process of legal decision-making and the adjudication of conflicts between rights.

There are three sets of reasons provided in the $N S$ decision, all of which add something unique to the discussion. The majority decision, penned by Chief Justice McLachlin, and the dissenting decision of Justice Abella construct the matter in a similar way, even though they arrive at different conclusions. Both say that when two conflicting rights are at issue, the court's approach should be one of balancing rather than establishing a hierarchy of rights. ${ }^{4}$ The majority decision explicitly argues against adopting a clear rule for or against the wearing of niqabs. ${ }^{5}$ Instead, in each case the judge must evaluate whether the wearing of the niqab poses a serious risk to the fairness of the trial. This is grounded in a contextual analysis focused on finding a just and appropriate balance between the rights at issue. ${ }^{6}$

The decision penned by Justice LeBel (and on behalf of Justice Rothstein) takes a very different approach. LeBel J. proposes a hierarchy of values whereby the value of religious freedom is to be subjugated to the value of open and transparent communication within the trial process. ${ }^{7}$ LeBel $\mathrm{J}$. frames the matter in relation to questions of multiculturalism and the foundational social values of the

$4 \quad$ NS, supra note 1 at paras 1-2 (per McLachlin), 81 (per Abella). The majority decision relies on Dagenais v Canadian Broadcasting Corp, [1994] 3 SCR 835, and $R v$ Mentuck, 2001 SCC 76, [2001] 3 SCR 442 to frame the balancing test used (see NS, supra note 1 at para 7).

$5 \quad$ NS, supra note 1 at paras 46-56.

$6 \quad$ Ibid at paras 46-47. For the formally stated test established by the court, see para 3.

7 Ibid at paras 71-78. 
Canadian political and legal tradition. ${ }^{8}$ Religion is one voice within the public sphere, and as such should be limited in any way necessary to preserve the openness and communicative capacity between individuals in public forums - especially in the court. In the view of LeBel J., the religious practice of wearing a niqab is opposed to the idea of open communication, and prevents the individual from engaging fully with the judicial institution. ${ }^{9}$ As a result, he proposes that a clear rule should be adopted to prohibit niqabs from being worn while giving testimony in a criminal trial.

The reason why the majority of the Court chooses the balancing analysis rather than a clear rule is because it wants to preserve the integrity of the interests protected by both of the rights at play. ${ }^{10}$ In most cases the fairness of the trial and accommodation of religious practices are completely compatible. It is only when the full realization of both becomes impossible that the balancing test is engaged. Accommodation and balance are intended to promote the "reconciliation" of the rights - to allow the religious practices without compromising the fairness of the trial. ${ }^{11}$

In this light, the majority decision sees the court as the protector of the individual rights embodied in the Charter, restricting them only on the grounds of good reason. ${ }^{12}$ In order to fully affirm the value of both rights at issue, the majority decision gives priority to the formal evaluative process of balancing over the substantive discussions of political and social values. In doing so, the majority disavows any commitment that would lead to giving preference to one right over the other. This, it is claimed, more accurately embodies the idea of 'neutrality', which is especially important when religious claims are at issue. $^{13}$

Despite its appearance, does the position of the majority actually avoid making a choice between various values? I suggest that it might not be as easy to distinguish between formal and substantive evaluative processes as implied by the majority decision. Surely, an analysis focused on balancing and reasonable justification for limiting rights relies on a robust conception of what counts as 'reasonable' and 'proportional'. Balancing requires an idea of how two things can be compared with each other. Balancing requires a scale, and reasonableness (or proportionality) requires a point of reference. My argument is that the Court's decision presupposes a conceptual framework that reflects a set of commitments to certain social and political values. We can find evidence of this framework and its philosophical basis by looking at how the Court applies the balancing analysis. But first we should look at what the Court says about the rights at issue in the NS case, to set the groundwork for considering the way that the balancing analysis is applied.

$8 \quad$ Ibid at para 72, LeBel describes constitutional protections, such as those found in the Charter, to be grounded in "....its political and legal traditions." Relying on the words of Chief Justice Dickson, LeBel J says that "The 'living tree' keeps growing, but always from its roots."

Ibid at para 77.

Ibid at para 32.

Ibid at paras 30-34.

Ibid at para 56.

13 Compare the two ideas of neutrality referred to by the majority decision (NS, supra note 1 at paras $31,50,55)$. The former is a 'thick' idea of neutrality based on the model offered by Justice LeBel, which requires the emptying of certain (religious) practices from public spaces such as the court. The latter is a more formal (or 'thin') idea of neutrality, which requires neither hindering nor favouring any particular religious belief. The latter model (found in the case $S L v$ Commission scolaire des Chènes, 2012 SCC 7, [2012] 1 SCR 235 at para 32) is adopted by the majority, and is related to the need for good reasons in limiting Charter rights. 
Religious freedom has had a vaguely defined place in the law since the earliest days of the western legal tradition. The separation of powers between the Catholic Church and the Roman Empire is a central part of the story of our system of law. ${ }^{14}$ The Court in NS pays homage to the importance of religion to Canadian law. This includes not only the swearing of oaths on religious $\operatorname{texts}^{15}$ but also a broader social commitment to tolerating and accommodating religious practices. ${ }^{16}$ In addition, one of the fundamental principles of the Charter is that the rights it protects (including religious freedom) can be limited only when there is a good reason for doing so. ${ }^{17}$ Therefore, a general restriction to religious practice within the legal context is unacceptable. "The answer is not to ban religion from the courtroom, transforming it into a 'neutral' space where witnesses park their religious convictions at the door."18 The Court envisions instead a reconciliation of religious with secular practices and values within the legal context. One should not disrupt the other in the form of an absolute rule, but instead be decided through a proportionate balance. ${ }^{19}$

Secondly, the right to a fair trial has a very different place in the history of our legal tradition. In NS, the majority decision characterizes it as a practice emerging from time immemorial, a foundational aspect of our system of criminal justice. The majority decision reflects on the fair trial right, guaranteed in s 11(d) of the Charter, as standing in close relation to the "principles of fundamental justice" entrenched in $\mathrm{s} 7$ of the Charter. ${ }^{20}$ The aspect of fair trial procedure at issue in this case is the practice of seeing a witness's face during cross-examination. The main concern is that the credibility or veracity of the witness's testimony will be more difficult to determine if their face cannot be seen. This carries with it the risk that an accused might be wrongfully imprisoned, which is of central concern to the legitimate rule of law. ${ }^{21}$ The Court pays great deference to these historically established practices, which can only be displaced "if shown to be erroneous or based on groundless prejudice...."22 The

14 For one of the most well-known historical discussions of the connection between religion and the law in the history of the western legal tradition, see Harold Berman, Law and Revolution: The Formation of the Western Legal Tradition, (Cambridge, MA: Harvard University Press, 1983). Berman's sequel to the original classic, Law and Revolution II: The Impact of the Protestant Reformations on the Western Legal Tradition, (Cambridge, MA: Belknap Press of Harvard University Press, 2003) is also quite helpful in framing the historical connection between religion and our legal tradition. For a very different view of the implications of that history, one that is stridently in favour of separating religion and legal institutions, see David Saunders, Anti-Lawyers: Religion and the Critics of Law and State (London: Routledge, 1997).

$15 \quad$ NS, supra note 1 at para 53.

16 Ibid at para 54. Some scholars have criticized the language of accommodation used by the court because it puts religious practices in a position subservient to other rights that more closely align with a secular worldview - for example, see Faisal Bhabha, "From Saumur to $L(S)$ : Tracing the Theory and Concept of Religious Freedom under Canadian Law" (2012) 58:2 Sup Ct L Rev 109.

17 Ibid at para 55-56.

$18 \quad$ Ibid at para 31.

19 Ibid at paras 32-33.

$20 \quad$ Ibid at para 15.

21 Ibid at para 38: "The right to a fair trial is a fundamental pillar without which the edifice of the rule of law would crumble. No less is at stake than an individual's liberty - his right to live in freedom unless the state proves beyond a reasonable doubt that he committed a crime meriting imprisonment. This is of crucial importance not only to the individual on trial, but to the public confidence in the judicial system."

22 Ibid at para 22. 
practice of seeing a witness's face during cross-examination is deeply rooted in our criminal justice system and requires "compelling evidence" to dislodge it. ${ }^{23}$

The question that naturally arises is how do we compare these two rights in order to balance them? Religious and fair trial practices appear to be about as different as two rights can be. The strategy taken by the Court is to equate them in terms of the effects - both 'harms' and 'benefits' - of allowing or disallowing NS to wear the niqab. ${ }^{24}$ This idea of comparison is central to the balancing analysis. It is important to remain aware of the diversity of the various individual and social interests at play when we look at how the Court interprets them in terms of 'harmful' and 'beneficial' effects.

In relation to the individual, the harm done in restricting religious freedom is more difficult to calculate than in restricting free trial rights. ${ }^{25}$ Generally speaking, identifying and protecting religious claims in law is a difficult task. There is a significant amount of academic discussion on this topic, which reaches well beyond the bounds of the $N S$ case. $^{26}$ One of the main difficulties is in articulating what is lost when an individual is forced to give up a religious practice - how does one apprehend and express the compromise of the condition of the soul, the soul's relation to God and one's standing in a religious community? The same difficulty does not apply to fair trial interests. The risk to the individual is very clear and identifiable - the individual will be wrongly punished, perhaps imprisoned. Loss of personal physical liberty is very tangible, whereas religious offensiveness is not.

In addition, the loss of some of the protections against wrongful punishment is not a direct infringement on personal liberty in the same way that loss of religious liberty is. The loss of religious freedom interferes with the liberty to direct one's life according to a matter of ultimate concern, which, as in $N S$, might directly affect one's ability to follow activities prescribed by that ultimate concern. Limiting the practices protecting the fairness of a trial might also result in a loss of personal liberty (being wrongly punished by the state); but punishment itself is not the fact at issue - rather, it is the risk of being punished wrongly. For religious freedom, there is no risk involved. What is being faced is the real limitation to religious practice. In terms of a fair trial, the individual experience is entirely one of risk - the risk of being punished wrongly.

Given these differences, comparing the two rights is difficult. The majority decision focuses on the very tangible nature of the harm of false imprisonment, such that it overshadows the more difficult to articulate harms that flow from the religious violation. ${ }^{27}$ Physical consequence that is empirically demonstrable (albeit it potential rather than actual) weighs much more strongly for the court than

$23 \quad$ Ibid at para 27.

24 Ibid at paras 36-42. The dissenting opinion of Justice Abella also uses harm as the key to working out the balance (ibid at para 80). It should be noted that the majority applies a form of the proportionality analysis regarding section 1 of the Charter, first developed in the case $R v$ Oakes, [1986] 1 SCR 103. The Oakes proportionality test is framed as weighing the positive and negative 'effects' of allowing a particular restriction of a right.

$25 \quad$ Ibid at para 36.

26 For example, see Winnifred Fallers Sullivan, The Impossibility of Religious Freedom (Princeton, Princeton University Press, 2005); Mark Witten, "Rationalist Influences in the Adjudication of Religious Freedoms in Canada" (2012) 32 Windsor Rev Legal and Soc Issues 91; and Paul Horwitz, "The Sources and Limits of Freedom of Religion in a Liberal Democracy: Section 2(a) and Beyond” (1996) 54 UT Fac L Rev 1.

27 This limitation - focusing on easily measurable factors - has been identified quite often. For an interesting example of how the more difficult to understand human experiences, which are often religious in nature, can be used to re-think the way that we define damages in the context of tort law, see Steven D Smith, "Legal Discourse and the De Facto Disestablishment" (1998) 81:2 Marq L Rev 203. 
spiritual consequence. This framework for giving order to rights through the balancing analysis presumes a fundamental division between physical and non-physical consequences. The fact that a risk of physical harm outweighs a sure spiritual harm is itself a profound statement of philosophical commitment that reflects a hierarchy of values.

The distinction between religious freedom and fair trial protections can also be seen in the Court's consideration of the social interests at play. The majority decision in NS rightly notes that any limitation to fair trial protections would compromise the public interest in maintaining justice. ${ }^{28}$ Wrongful punishment is one of the gravest injustices, and failing to protect it undermines the legitimate rule of law. ${ }^{29}$ On the other hand, requiring Muslim women to remove their niqabs to testify in court will prejudice them in criminal proceedings. ${ }^{30}$ If they are victims of crimes then they will be unable to access the institutional mechanisms of justice and give evidence of their suffering. Likewise, if they are accused of committing crimes then they will be unable to speak in their own defence. ${ }^{31}$

This part of the majority opinion clearly shows some of its philosophical biases. Greater interest is taken in the perceptions of justice of the social majority than in the injustices experienced by the social (religious) minority. Regardless of the merits of such a position, it involves a substantive commitment to a particular vision of social and legal institutions - it is a statement of value. The influence of this set of values on the decision can be seen in the way that the majority decision in $N S$ responds to the negative experiences of Muslim women, and how that experience is translated into terms related to the interests of the general public.

The majority decision describes the social 'harms' resulting from limitations to both of the rights in different terms. On the one hand, individuals facing prosecution are seen as the passive victims of state power, and limiting protection for them is a matter that speaks to the legitimacy of law itself. On the other hand, restrictions to Muslim women in accessing criminal justice are framed against the backdrop of the law's evolution regarding women's rights. ${ }^{32}$ Emphasis is placed on the great effort that has been made by the courts to bridge the gap between women and legal institutions. The implication is that Muslim women need to meet the court half way - that the blockages they are bound to experience are a result of their own choices rather than institutionalized discrimination. Muslim women are portrayed as active and able to avoid their victimization.

Justice Abella contested this view of religious choice, arguing that religious obligation cannot be understood simply as a matter of personal preference or free choice. ${ }^{33}$ For Abella J., the majority's position regarding Muslim women is offensive to the rule of law (and perceptions of justice) - it is unjust to ask Muslim women to choose between their religion and access to justice. Abella J.'s argument indicates nicely that an important feature of the philosophical framework of the majority decision is the presumed distinction between a Muslim woman's agency and her religious practices. The goal of law, in this view, is to empower individuals to make their own choice, independent of religious commitment. Likewise, it is not the role of law to protect people from the consequences of

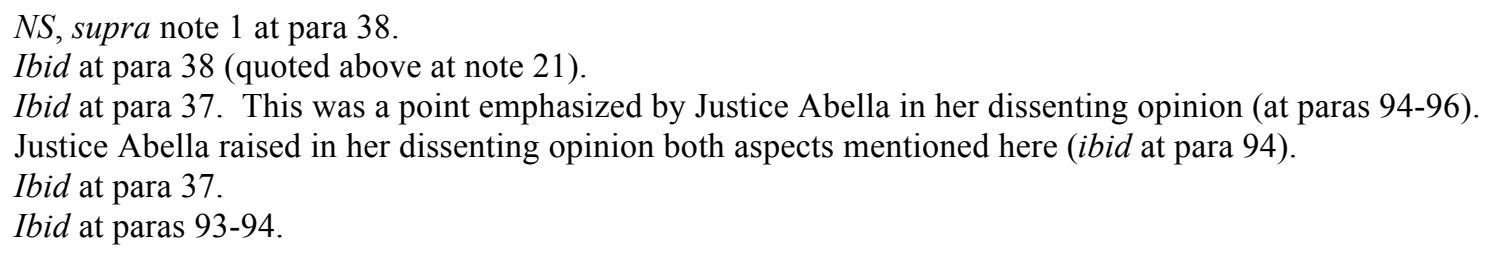


their own choices. Religious identity, as expressed through religious practice, is seen as similar to other personal preferences, which means that the consequences of restricting it are of less importance to the legal decision-making process. This deeply affects what the court sees as reasonably required to accommodate religious practice.

In conclusion, the majority takes the view that "... where the liberty of the accused is at stake, the witness' evidence is central to the case and her credibility vital, the possibility of a wrongful conviction must weigh heavily in the balance, favouring removal of the niqab." ${ }^{34}$ Contrary to this, Abella finds the exclusion of Muslim women from the criminal justice system to be more reprehensible than the moderate risk posed by a veiled witness to trial fairness. ${ }^{35}$ What we see in this point of disagreement is one of two things: either 1) there is a remarkable amount of room for subjective perception to influence the evaluation of the severity of harm, or 2) there is significant influence of differing frameworks in the calculation of balance. If the former is the case then the deciding feature of the decision is based on which set of harms appears to be more reprehensible for the social majority, which can hardly be described as a 'neutral' form of balancing. On the other hand, if the latter is the case, then we have further confirmation of the significant role played by the conceptual framework of the Court's decision.

My point is not to resolve all of the many issues that arise here, but to show that the balancing test employed in NS does not escape them. In other words, the majority decision failed in its attempt to avoid the substantive issues raised by Justice LeBel. The Court's decision is not an objective weighing of the effects, as if 'harm' and 'benefit' are neutral or common measures for both rights. Instead we find the Court relying on a complex web of philosophical commitments that provide a framework for their decision. The structure of this framework touches on the ongoing debates regarding social goods, public values and notions of justice. What we think about these questions is of ultimate importance because the balancing analysis becomes possible only after they are applied as a filter to the meaning of the factual circumstances and rights at play.

I do not suggest that resolving a conflict between rights should be done from a 'view from nowhere.' If anything, $N S$ demonstrates the opposite - that our deliberations regarding the adjudication of conflicts between rights must reach beyond the idea of balancing as a neutral and objective activity, and engage with the concepts and philosophical commitments that animate our ideas of law, religion, social goods, public values and justice. The main problem with the majority analysis in NS is that it fails to do that. What is more, I will argue that the philosophical presumptions operating in the court's balancing approach negatively affect its ability to critically reflect on the content of those presumptions. In the following two sections I will look at a couple of possibilities for re-thinking the conceptual framework of legal analysis, and what might be needed to engage these ideas in ongoing critical reflection.

\section{THE INCOMMENSURABILITY THESIS}

The incommensurability thesis provides a useful point of departure from the $N S$ case into the discussion of the conceptual frameworks relevant to legal decision-making. The incommensurability thesis challenges one of the main assumptions of the balancing analysis: that conflicting rights can be compared to each other (that the rights are somehow commensurable). The main thrust of the

Ibid at para 44 .

Ibid at paras 93-96, 109. 
incommensurability thesis is that there is no common metric for weighing different rights and interests (or values and goods) - they cannot be reduced beyond a certain point. ${ }^{36}$ Each one has to be treated as significant in its own right. In order to make sense of the decision-making process we therefore have to provide a role for social values and commitments as an aspect of legal reasoning.

Although there are some great benefits in drawing attention to the importance of social values and commitments in the decision-making process, the incommensurability thesis also has drawbacks. Primarily, as I will elaborate below, it does not provide a satisfactory basis for critical engagement with these conceptual frameworks. The incommensurability thesis is typically seen in opposition to the idea of the balancing analysis, but I suggest that when we look at it closer, it actually seems to rely on similar philosophical presuppositions and discursive limitations as the majority decision in the $N S$ case. The incommensurability thesis serves to sharpen our understanding of the balancing analysis and to narrow our search for a way to critically engage with the conceptual frameworks undergirding legal discourse.

\section{A. Plurality of Values and Reasons}

Cass Sunstein authored one of the leading articles exploring the relevance of incommensurability to the law. ${ }^{37}$ He argues that incommensurability is a good thing, and that its use in law will help to clarify our discussions of various legal questions, especially helping us understand what is at stake in hard cases. ${ }^{38}$ Sunstein contends that the plurality of values encountered in human life cannot be reduced to a single conception, like happiness or utility. ${ }^{39}$ In order to avoid the reductive tendency of value monism, values should be viewed as incommensurable. Legal decision-making is an act of value judgment, which involves a decision of which values should be used in adjudicating different types of cases. Hence, the role of law is to "...constrain prevailing kinds of valuation."

The import of this view can best be seen through examples. Sunstein proposes that the rules prohibiting the sale of children or to offer money for sex are best understood as value judgments based on the incommensurability of money and the responsibility to care for children or the meaning of sexual

36 A useful source for the discussion of incommensurability is a collected volume edited by Ruth Chang, Incommensurability, Incomparability, and Practical Reason (Cambridge, MA: Harvard University Press, 1997). It should be noted at the outset that the topic of incommensurability is multifaceted. My relatively narrow account of the topic focuses on what, in my view, helps us grapple with the difficulties presented in the NS case. My concern here is not with making a decisive claim about the philosophical discussion regarding incommensurability, incomparability and practical reasoning - a broad (and burgeoning) subject, to be sure. Instead, my portrait of the 'incommensurability thesis' is intended to aid in uncovering some of the philosophical 'heavy spots' that often get passed over presumptively in legal analysis. I should note that in Chang's volume there are several chapters that I see standing in line with the themes developed in this paper. For example, the arguments put forward by Charles Taylor, Donald Regan and Elijah Millgram (and to some extent Elizabeth Anderson) resonate deeply with my reflections on the theory of Alasdair MacIntyre given in part three of this paper. My positive and critical comments regarding the 'incommensurability thesis' should be seen in this context. 
relationships. $^{41}$ Money is judged to be of a different kind of value than that found in parental responsibility or sexual relationships, which makes it wrong to act in such a way that assumes the value of the latter is commensurable with the former. According to Sunstein, to reduce human value to a single measure, or to assume that conflicting values can always be made commensurable, obfuscates our understanding of human value and behaviour. ${ }^{42}$ Therefore, failing to appreciate the irreducibility of human values will make some legal concepts impossible to understand. ${ }^{43}$

Richard Warner provides a similar view to Sunstein, but frames the matter in terms somewhat more familiar to the legal ear. ${ }^{44} \mathrm{He}$ describes incommensurability as a prior judgment that precludes the use of certain reasons (rather than Sunstein's reference to the less-specific idea of value) in specific contexts. $^{45}$ Incommensurability is constructed through the commitments we make, which, by their nature, require the exclusion of some reasons from being considered during the decision-making process. $^{46}$ Warner argues that this view of incommensurability not only helps us make better sense of legal and policy decisions but it also affirms the inviolable value and dignity of individuals and the restrictions that this imposes on public decision-making. ${ }^{47}$

There is certainly an intuitive appeal to the arguments made by Sunstein and Warner. How can things as different as money and familial relationships be boiled down to a single equalizing factor? It does not seem possible. This basic intuitive observation provides a fairly powerful argument for expanding our view of what should be taken into account while discussing legal rules. The incommensurability thesis encourages us to give regard to all of human experience as potentially relevant, and militates against assuming that one aspect of enquiry or one notion of value or reason should be given deferential authority. To do otherwise would be contrary to our human experience. ${ }^{48}$

It should be noted that there is a point of overlap here with the view taken by the majority in $N S$, which affirmed the equal importance of the rights at play in the case. This led the Court to deny the possibility of developing a hierarchy of rights - to do so would threaten the integrity of the competing rights. The resonance this has with Sunstein and Warner's value pluralism is self-evident. However, the difference between them arises when they are forced to turn these abstract ideas into practical solutions

41 Sunstein discusses a whole range of examples throughout the essay, and includes a section dealing specifically with conflicts between uses of money and other values (Ibid at 785-790). Similar examples are used regularly in other academic works on incommensurability. For example, Richard Warner discusses extensively a hypothetical example of being asked to sell his daughter (see "Excluding Reasons", infra note 44 at 438-441).

42 Sunstein, supra note 37 at 794.

43 Sunstein spends a significant portion of his essay discussing how incommensurability helps us understand different areas of law, such as civil equality, free speech, environmental protections, the remedy of specific performance and feminist legal claims (see ibid at 824-853).

44 The two articles by Richard Warner that I rely on are: "Excluding Reasons: Impossible Comparisons and the Law" (1995) 15:3 Oxford J Legal Stud 431 ["Excluding Reasons"], and "Does Incommensurability Matter? Incommensurability and Public Policy" (1998) 146:5 U Pa L Rev 1287 ["Incommensurability and Public Policy"].

45 Warner justifies looking at reasons instead of values because values can easily be understood as constituting a form of reason (See ibid at 1292). There are certainly echoes of the exclusion of reason in Sunstein's text (See e.g. supra note 37 at 801-804).

46 Warner, "Excluding Reasons", supra note 44 at 439. A similar argument is provided by Richard H Pildes in his article "The Structural Conception of Rights and Judicial Balancing" (2002) 6:2 Rev Const Stud 179 at 184.

47 Warner, "Excluding Reasons", supra note 44 at 433.

48 Sunstein, supra note 37 at 854-855. 
for resolving a conflict between rights. The majority in NS adopts a formal analysis of balancing the harmful and beneficial effects of the decision. Sunstein and Warner resist this approach, claiming that to reduce the complexity of values to a single (or set of) concept(s) through imposed terms of comparability, even in a formal sense, has a transformative effect on the values in question. ${ }^{49}$

This leads us to one of the main puzzles faced by the incommensurability thesis. How are decisions made when rights or values come into direct conflict with each other? Are we to rely on pure impulsive choice? If rights and values are truly incommensurable, then how can they ever be engaged in such a way as to decide between them in a particular case? In what way can these decisions be articulated coherently so as to make sense to us and to others? For some critics, this question shows that the incommensurability thesis unjustifiably devalues the human capacity to communicate. ${ }^{50}$ If we cannot compare values and rights, then what is to say that we can compare other complex things, like languages, religions or cultural (and legal) traditions?

There are multiple ways to attempt a solution to this puzzle, even amongst the proponents of the incommensurability thesis. Some, like Paul-Erik Veel, contend that the incommensurability thesis does not lead us to deny judicial practices of balancing or proportionality. ${ }^{51}$ Veel argues that we can avoid weighing the 'goodness' of values if they can be described as equal in relation to a 'choice rule'. ${ }^{2}$ The idea is that if a scale can be created to measure the severity of the impact of a choice on two opposing rights in their own terms, not in relation to each other, and if the rights at issue are considered to be equally worthy of full realization, then the severity of the impact of the choices on each right can be used as a reasonable way to make a decision in a particular case. ${ }^{53}$

Veel's theory appears to be consistent with the analysis taken by the Court in NS, where the effects on both of the rights are considered individually and weighed against each other. It is not clear, however, whether this approach is able to avoid the transformative effects of making comparisons, as warned against by Sunstein and Warner. As was argued earlier, the description of harmful and beneficial effects on the rights at issue in NS does appear to have had a transformative effect on the nature of those rights. ${ }^{54}$ The Court's refusal to adopt and impose a constructed hierarchy of rights did not ensure their equal treatment. Although this does not disprove Veel's theory, it suggests rather strongly the impossibility of realizing it in practice.

A more technical - but in my view important - criticism of Veel's theory is that it requires pure symmetrical equality between the rights at issue in order for them to be balanced. Such a view of symmetry requires a referent point. The workability of Veel's balancing theory therefore depends on determining whether the notion of symmetrical equality is appropriate in the particular circumstances of

\footnotetext{
Ibid at 815 .

For example, see H Patrick Glenn, “Are Legal Traditions Incommensurable?” (2001) 49:1 Am J Comp L 133.

Paul-Erik N Veel, "Incommensurability, Proportionality, and Rational Legal Decision-Making” (2010) 4:2 Law \& Ethics of Human Rights 177 at 186.

52 Ibid at 198-201. Veel's theory is an adaptation of the 'Nash Bargaining Solution'.

53 Ibid at 200-201.

54 This was seen in two ways: 1) the way that the harm to Muslim women was recast as a result of their active choice rather than passive victimization, and 2) the way that the risk of physical harm was given priority over certain religious harm because of its physical and demonstrable effects.
} 
each case. ${ }^{55}$ Although it may not be necessary to have a numeric formula of 'the good' to compare rights, there must at very least be a political community that agrees on the symmetric equality of the rights at issue - a point that Veel, to his credit, acknowledged. ${ }^{56}$ This shows that balancing incommensurable values (or rights) is not a neutral or value-free process. Instead it engages a conceptual framework that is grounded in the social and political processes of recognizing and interpreting values (or rights and interests). ${ }^{57}$

\section{B. Incommensurability, Social Commitments, Collective Identity and Rational Enquiry}

For Sunstein and Warner, reconciliation of the plurality of values in the legal decision-making process requires us to draw on our collective identities and social commitments in order to guide the adjudication of particular cases. ${ }^{58}$ To re-frame this in a way consistent with the language used so far, the reconciliation of rights (or values) draws on the conceptual framework provided by social discourse (collective identity for Sunstein, social commitments for Warner). Where there is disagreement about what our social commitments demand for right conduct, such as when rights conflict with each other, as in the $N S$ case, the courts (and other public decision-makers) must act as interpreters of our social commitments and identity. ${ }^{59}$

What was left unaddressed in the majority decision of $N S$, and what seemed to be lacking in Veel's account of the balancing analysis (the role of conceptual frameworks), is openly recognized and embraced by Sunstein and Warner. Although this appears to be a step in the right direction, we cannot stop at the mere recognition of the importance of conceptual frameworks, but have to also ask how the court is to utilize them. What guides the interpretation and understanding of them? How are they formed and justified? In short, how do we engage with them critically and rationally? ${ }^{60}$ I argue that the answers provided by Sunstein and Warner do not develop a mechanism for looking beyond the particularities of a given conceptual framework.

55 This is what Veel sets out to do in the final portion of his article, discussing the applicability of symmetry to cases of statutory law (ibid at 220), common law (ibid at 222), competing private constitutional rights (ibid at 224) and competition between private constitutional rights and public interests (ibid at 225).

$56 \quad$ Ibid at 219.

57 There are other proponents of the incommensurability thesis that attempt to devise strategies for making rational choices between rights or values. Some of these theories propose a model for comparing rights or values. No one attempts as direct, or convincing, of a defence of the balancing analysis as Veel, which is why I focus on him exclusively here. For some of these other examples, see Leo Katz, "Incommensurable Choices and the Problem of Moral Ignorance" (1998) 146:5 U Pa L Rev 1465; Virgílio Afonso Da Silva, "Comparing the Incommensurable: Constitutional Principles, Balancing and Rational Decision" (2011) 31:2 Oxford JLegal Stud 273; and Pildes, supra note 46.

58 See Warner, "Excluding Reasons", supra note 44 at 438-443, and "Incommensurability and Public Policy", supra note 44 at 1294-1299 and 1319-1323. Warner also sees this at relevant to individual decision-making ("Excluding Reasons", supra note 44 at 438 ).

$59 \quad$ Ibid at 456. Also see Sunstein, supra note 37 at 857.

60 It should be noted that Sunstein and Warner argue for a view of incommensurability that is not apposite to the 'rationality' of decision-making (see Warner, "Excluding Reasons", supra note 44 at 427; and Sunstein, supra note 37 at 811). There are others who argue for a stronger form of incommensurability, where decision-making does not depend on truly rational categories. Stavros Tsakyrakis proposes such a view (see "Proportionality: An Assault on Human Rights?" (2009) 7:3 International Journal of Constitutional Law 468), as does Joseph Raz (see, The Morality of Freedom (Oxford: Oxford University Press, 1986) or "Incommensurability and Agency" in Chang, supra note 36 at 110). I will not deal here with the arguments that distinguish between stronger and weaker claims of incommensurability. 
For Sunstein, there is no absolute rule as to which values should apply in a given situation. Instead, the valuation process is a struggle that must be engaged in with each particular case, and the values chosen are based upon higher-order considerations of what constitutes the good life and a good political system. ${ }^{61}$ In order to decide between competing incommensurable goods depends on achieving a certain type of social self-understanding, which requires us "...to be clear about what we value most deeply and to make choices that properly express the deepest valuations." ${ }^{62}$ He suggests that this may require "...a form of narrative continuity within a life or within a society." ${ }^{\circ 3}$ He goes on to argue that the idea of incommensurability helps to construct the social institutions that foster our social values. ${ }^{64}$ It is in this way that incommensurability produces for itself the raw materials (foundational values) necessary to make legal decisions. ${ }^{65}$

Although this certainly carries some appeal, in that it turns to social institutions rather than esoteric universal ideas to find guidance for principles of right conduct (and legal decision-making), it leaves itself open to the criticism of self-referentiality. The system Sunstein envisions is totally self-enclosed. He seems to presume that social self-understanding will always be able to produce a satisfactory resolution to conflicts that arise between values (or rights). This leaves his theory without a mechanism for engaging in critical self-reflection, or for participating in dialogue that reaches beyond the given conceptual framework. A view from outside the system will be disregarded as irrelevant since it is based on a different social self-understanding.

Warner takes his theory down a route similar to Sunstein. As mentioned earlier, in Warner's theory it is the core commitments of a society that act as the ultimate guide for the legal decision-making process. Drawing on the work of John Finnis, Warner takes the view that social communities simply adopt a set of social commitments for themselves. ${ }^{66}$ Warner suggests that neither is this the same thing as assuming a common metric for weighing values, nor is it an irrational exercise. A public decision-maker must explain and provide reasons for why it has adopted its set of commitments. ${ }^{67}$ Different and mutually exclusive choices may both have reasons, and making one choice instead of another is not irrational when it is made for the reasons provided in its defence. ${ }^{68}$ For Warner, some disagreement in our

61 Sunstein, supra note 37 at 855 .

62 Ibid at 857.

63 Ibid at 856 .

64 See $i b i d$ at 826 , where he argues that the language of incommensurability creates space for the growth of love within the family, reason within political life and worship in religion.

65 Ibid at 805, "Incommensurability operates as an obstacle to certain sorts of behavior; but it constitutes others, and makes them an option for us. For this reason, both social norms and life might insist that incommensurability of various sorts is desirable as a means of maintaining attitudes and relationships that are parts of good lives."

66 Warner, "Incommensurability and Public Policy", supra note 44 at 1321. For John Finnis' theory in his own words, see his essay "Natural Law and Legal Reasoning" (1990) 38 Clev St L Rev 1. I find it somewhat surprising that an otherwise conservative natural law theorist puts so much stock into choice and circumscribes so drastically the importance of human rationality in creating law. One possible explanation for this is that he wants to draw greater attention to the role of the community in the creation of legal meaning and the importance of history in understanding and developing those meanings. Another explanation would be in the fact that he distinguishes between law and moral reasoning, describing the former as technical in nature (ibid at 5-6).

67 Warner, "Incommensurability and Public Policy," supra note 44 at 1321.

68 See ibid at 1321-1323. 
commitments is natural and does not preclude the reasons we have for adopting a commitment; it is just that the reasons we find compelling may not be compelling to everyone else.

In my view, Warner's theory does not fare better than Sunstein's in addressing what is involved in reasoning about our primary social commitments. He appears to be avoiding the question by redefining its terms. Warner suggests that the public choice of a set of social commitments is to be justified by nothing more than a statement of the reasons leading to a particular commitment. ${ }^{69}$ The problem here is that we are then put in the position of evaluating between commitments solely in terms of the reasons offered for them, without the ability to ask or answer whether one set of reasons for social commitments is more compelling than a rival set. This involves the same types of questions we faced when deciding between conflicting values. The matter is displaced but not resolved. As we saw with Sunstein, Warner's theory also leads us to a self-enclosed view of the conceptual frameworks that undergird legal decision-making, which deprives us of the resources needed to fully engage them in critical reflection.

\section{Shared Limitations between the Incommensurability Thesis and the NS Approach}

It should be remembered that the incommensurability thesis has helped to articulate some of the limitations and difficulties inherent in the balancing analysis. Emphasizing the plurality of human values and reasons attunes us to some difficulties that arise when rights (or values) are forced into comparison. Even more significant than this, is the recognition of the important role of political and social conceptual frameworks in the decision-making process. Despite these positive contributions, the incommensurability thesis is limited in its critical capability. Although conceptual frameworks are recognized as important, there is an obvious struggle to develop a way of engaging them in dialogue that reaches beyond their inherent boundaries.

When we look at the movement in analysis between the various $N S$ decisions, and between $N S$ and the incommensurability thesis, we can see a type of cascade effect occurring. The majority decision in $N S$ attempted to move away from the raw assertion of primary and subsidiary values given by Justice LeBel. As we saw, this strategy did not avoid the influence of value commitments, which still operated in the form of a presupposed conceptual framework. The incommensurability thesis describes this problem well, and goes on to argue that legal rules and the decision-making process should be understood and interpreted through the conceptual frameworks of our chosen social commitments and identities. But this does not escape the problem because the understanding of these frameworks is restricted to the choices and self-perceived identities of the social community in question.

In the incommensurability thesis, the process of reflecting on the conceptual frameworks used in legal decision-making is not altogether dissimilar from the approach taken by Justice LeBel in NS. Both adopt a source for social values that is not disposed to critical reflection - for Justice LeBel, it is the principles of constitutionalism and democracy; for the incommensurability thesis, it is the commitments or self-understanding of a social community. Although from the outside the incommensurability thesis looks to have advanced beyond the ideas in $N S$, it is in fact very much bound by those same concerns. Indeed it seems that those concerns have taken on new life and become even more pressing.

69 Admittedly, the openness proposed by Warner in adopting social commitments would likely attract sufficient public scrutiny to prevent wanton decision-making - certainly the reasons for the commitment will have to be compelling to at least the majority of the public. Unfortunately, space does not allow for discussion of the theories regarding pragmatism and public discourse (see e.g. Stout, supra note 3). 
The connection between the incommensurability thesis and $N S$ is not limited to the approach taken by Justice LeBel. H Patrick Glenn's critique of the incommensurability thesis helps to clarify this connection between them. Glenn argues that the philosophical basis of the incommensurability thesis is grounded in a set of assertions particularly modern in outlook - the insistence on "... singularity, particularity and diversity... [and] an abstract individual, free of apparent particularity, choosing amongst the particularities of the world." ${ }^{70}$ This description resonates with what we have seen in the discussion of the incommensurability thesis. The philosophical presumptions earlier identified in the majority analysis of $N S$ - i.e. preference for empirically demonstrable harms, preference for perceptions of justice of the social majority, and the view of a fractured self as it relates to choice in terms of religious identity and practice - all have a distinctive modern philosophic flare that resonates with Glenn's critique.

This provides a new direction for our investigation. We should now consider which philosophical conditions would help us engage in critical reflection on the conceptual frameworks underlying the legal decision-making process. Where can we turn to for a theory that does not share in the same philosophical outlook shared by the NS case and the incommensurability thesis? One place that I suggest we can look is to the notion of tradition, as described by Alasdair MacIntyre. MacIntyre's theory opens the door to a different way of approaching the dialogue between various social voices, which enables a level of engagement between religious and non-religious voices and interests that is not possible within the analysis of $N S$ or the incommensurability thesis.

\section{ALASDAIR MACINTYRE - TRADITION, RATIONAL ENQUIRY AND LEGAL DISCOURSE}

MacIntyre's theory attempts to articulate what is required for the rational deliberation within and between traditions. Although his theory is pitched at a high level of social abstraction, taking on the idea of 'liberalism' and its effects on moral philosophy, it also bears relevance to questions of law, and specifically to the issues being discussed in this paper. My argument is that MacIntyre's theory provides a way of thinking about conceptual frameworks that stands outside of the philosophical presumptions shared by the $N S$ balancing analysis and the incommensurability thesis. His theory challenges the idea of individual preference in modern liberal thought, and replaces it with the idea of tradition as a site for rational enquiry. He focuses not only on the importance of social and historical context to rational discourse, but also argues that communal participation in the pursuit of an understanding of the ultimate human good is constitutive of rational enquiry itself. This view of reason and rational enquiry emphasizes the importance of engaging diverse perspectives in a common discourse.

\section{A. Fractured Rational Enquiry through Preference}

MacIntyre begins his classic work After Virtue by discussing what appears to be an impasse in contemporary moral and ethical debate. ${ }^{71}$ This debate is not simply protracted but seems to have the elements of intractability - "There seems to be no rational way of securing moral agreement in our

Glenn, supra note 50 at 138.

Alasdair MacIntyre, After Virtue: A Study in Moral Theory, 3d ed (Notre Dame: University of Notre Dame Press, 2007)

[After Virtue] at ch 2. 
culture."72 MacIntyre suggests three features of the debate that lead it to this point of impasse. First, there is "...conceptual incommensurability of the rival arguments..." insofar as there does not appear to be a way to rationally connect the different premises on which the various arguments rely and the normative bases of the claims they make. ${ }^{73}$ Secondly, each different argument purports to be rational and objective in a way impersonal to the relationships between the parties and independent of the particular contexts of each situation. ${ }^{74}$ Thirdly, the philosophical bases of the different arguments seem to be downplayed in favour of particular voices - the philosophical justifications are separated from their historical/conceptual contexts. ${ }^{75}$

Echoing Glenn's critique of the incommensurability thesis, MacIntyre describes the growing reliance on the notion of 'preference' as one of the central features of modern moral discourse. ${ }^{76}$ That is to say that every individual is encouraged to propose and live by their own conception of the good, and that no single conception of the good can be used to guide the lives of everyone. ${ }^{77}$ This notion of preference alters the idea of justification for selecting courses of action by replacing rational moral evaluation with a form of free-market competition. ${ }^{78}$ This has resulted in the separation of the various spheres of life, where the goods pursued in one area are distinguished from those pursued in another. Individuals become responsible for giving order to all of the various goods of life, and the public space is constructed to protect the separation of goods as well as the primacy of the individual in the creation and pursuit of those goods. ${ }^{79}$

MacIntyre argues that as this idea of preference took hold in modern society it changed the way we conceived of rational debate and the resolution of philosophical disagreements. What once engaged all of society in collective dialogue, between philosophical, religious and political voices, became the sole prerogative of the individual. Moreover, the resolution of conflicting interpretations of what is required in a given situation was also removed from broader social dialogue and formalized in the process of legal adjudication, which was charged with resolving conflicts without invoking an overall conception of the human good. Indeed, in this analysis "The lawyers, not the philosophers, are the clergy of liberalism." 80

The meaning and implications of this critique become clearer when viewed through the lens of the issues raised in the $N S$ decision and the incommensurability thesis. First, regarding $N S$, I have argued that the balancing analysis employed by the majority unsuccessfully attempts to avoid the value judgments associated with adopting a hierarchy of rights. This failure can be seen in the influence of a conceptual framework (built around certain value judgments) in the application of the balancing analysis. MacIntyre's critique elaborates on this in a slightly different way. For him, the denial in NS of any value judgment would be indicative of the modern liberal effort to construct legal institutions in

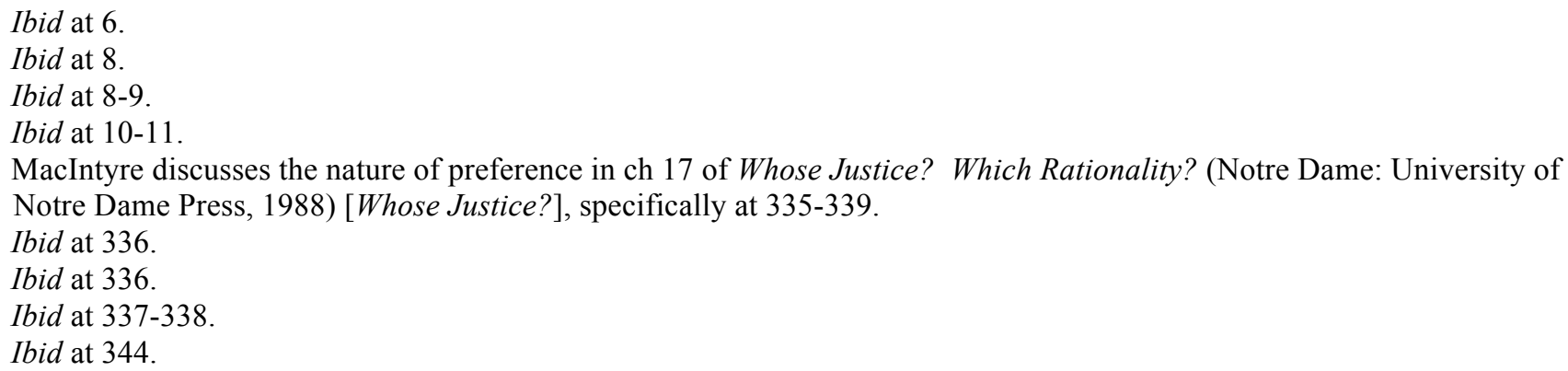


such a way as to avoid the use of any theory of the ultimate human good - to remain 'neutral'. For MacIntyre, this effort would be bound to fail for a couple of reasons. First, because in taking this view the court is actually relying on the modern model of moral reasoning, which is based on certain value judgments of what is 'good' (i.e. individual preference) and 'bad' (i.e. whatever resists the freedom of individual preference). ${ }^{81}$ Secondly, establishing preference as the basis of legal adjudication imposes limitations on our ability to engage in critical (rational) reflection on how to resolve conflicts between rights. It breaks apart the discourse of reason that once unified all of human thought, and denies legal adjudication access to a broad spectrum of human experience, understanding and discourse. We should therefore not be surprised when difficulties arise in resolving conflicts between rights within the balancing analysis. Legal discourse grounded on this fractured idea of human reason simply does not have the conceptual tools necessary to develop an analytic framework capable of navigating through the complex range of interests, goods and claims that arise in a case involving a conflict of rights.

Regarding the incommensurability thesis, I have argued that it is limited in its ability to engage in critical reflection on the conceptual frameworks provided by the social commitments or selfunderstanding of particular communities. I suggested that this is related to the self-enclosed nature of the incommensurability thesis. MacIntyre would add that this phenomenon shows that the community's social commitments or self-understanding functions in a way similar to individual preference in modern moral philosophy. This deference to community preference indicates that the underlying philosophical structure of the incommensurability thesis is the same as that of the NS case, which results in the fragmentation of human reason and giving preference to formal processes of conflict resolution rather than engaging with its substantive aspects. The result is that one of the central arguments made by the incommensurability thesis - that our legal discourse is grounded in social context (commitments and self-understandings) - is in fact based upon a process that aspires to be value-free and abstracted from social moorings. The importance ascribed to social discourses in the incommensurability thesis involves a contradiction. Its commitment to the value of the plurality of voices in society is underwritten by a deeper commitment to value-free discourse.

In these critiques of the balancing analysis and the incommensurability thesis we can see some of the limitations of rational discourse that MacIntyre intends to address. The fragmentation of human reason renders ambiguous the origin and meaning of the conceptual frameworks operating in legal adjudication. Focusing on individual preference destroys the discursive value of the various voices within society (religious, philosophical, familial, etc.) because it denies the philosophical structure that unites them in a single discourse working towards the common end of human understanding. Formal legal adjudicatory procedures are looked to as a way to unify the various social discourses, but built into the adjudicatory process are presumptions related to the primacy of individual preference that prevent the unification that is sought. This perpetuates a cycle of constant fracturing of human understanding and seeking for unity in formal structures, which presupposes disunity from the start. MacIntyre attempts to disrupt this cyclical narrative of disunity, challenging the presumptions leading to the fractured vision of human thought/reason, and to articulate a view of rational enquiry that is able to engage more openly and comprehensively with the whole of human experience and understanding.

$81 \quad$ Ibid at 345. 


\section{B. Embedding Reason in Tradition - Participation and the Ultimate Good}

We now have to explore how the positive aspects of MacIntyre's theory propose to provide the philosophical conditions necessary for engaging with the broad range of issues that arise in conflicts between rights. The main thrust of MacIntyre's theory, which directly responds to the idea of preference, is that reason is always embodied within a web of historical, cultural, and social institutions and relationships, and that this unity provides the background against which conflicts between rights can be resolved. At a basic level there is some overlap between MacIntyre's theory and the incommensurability thesis; most notably, they agree that human reason is embedded within our social institutions and relationships. What distinguishes them is the way that the social embedding of reason is related to the process of rational enquiry. As we have already discussed at length, the incommensurability thesis sees the process of rational enquiry as grounded in our understanding of social commitments and self-understanding (which seems to ultimately be cast in the form of community preference). MacIntyre, to the contrary, grounds the process of rational enquiry in the notion of tradition. Two unique features of MacIntyre's notion of tradition are the importance of participation and the pursuit of the ultimate good in the process of rational enquiry.

For MacIntyre, human understanding is something that we participate in with others in the context of communities that extend and evolve over time. The ideas and institutions we are connected to have been received and will be passed on. ${ }^{82}$ It is in this way that social relationships, institutions, languages and philosophical conceptions are to be thought of as 'traditions'. We all inherit our ideas from the traditions within which we find ourselves a part of. ${ }^{83}$ There is no place of human understanding or rational expression that exists separately from its embodiment within a tradition. ${ }^{84}$ For MacIntyre, individual free thought always emerges out of participation in and a commitment to a community or tradition. Greatness and success at something (such as chess) first requires disciplined learning of the established practice and its rules. ${ }^{85}$ A pupil must first learn from a master. Only after mastering the received practice can she then push the practice and its ideas beyond existing convention. ${ }^{86}$ Ideas that are original and effective - freethinking itself - are therefore grounded in existing traditions.

It is important to add that MacIntyre sees participation in a tradition in terms of the common pursuit of an ultimate end, or an ultimate good (i.e. teleology). For MacIntyre, developing an understanding of the ultimate good or ultimate end is a dynamic process that is neither apprehended through purely scientific and abstract reflection nor through a purely pragmatic and institutional process. Rather, it is a combination of both. For MacIntyre, Aristotle captured this best when he added to Plato's theory of the

\footnotetext{
82 MacIntyre grounds his theory in the correspondence theory of knowledge, and how it is reflected in the truth claims that develop and change over time through tradition (ibid at 355-361). Similar arguments regarding the correspondence theory of knowledge can be found in Michael Oakeshott, Experience and its Modes (Cambridge: Cambridge University Press, 1933), especially in ch 1. Jeffrey Stout, although a critic of MacIntyre's anti-liberalism, also argues for a similar evolution of conceptions of truth from what is received towards an undefined end - see Stout, supra note 3, especially ch 11 and 12, where he argues for and develops a concept of "pragmatism" which involves the pursuit of truth grounded in a form of tradition and practice not altogether dissimilar from MacIntyre's theory. MacIntyre, Whose Justice?, supra note 76 at 221.

84 MacIntyre, After Virtue, supra note 71 at 222. Also see MacIntyre, Whose Justice?, supra note 76 at 401.

85 MacIntyre, After Virtue, supra note 71 at 190.

86 MacIntyre notes that practices do not have goals that are fixed for all of time, but that they are fluid, even despite their complex reliance on institutionalization (see ibid at 193-194).
} 
forms the idea that the forms can only be understood through their various incarnations. ${ }^{87}$ In other words, abstract theoretical understanding is only possible when coupled with practical knowledge. For Aristotle this meant that to know what is a just polis requires participation in a political community ${ }^{88}$ To know the ultimate end is to participate with others in the pursuit of an ultimate end. As a result, the idea of the ultimate good is not a static thing; rather, it is only through the quest for the ultimate good that we come to understand what the ultimate goal of the quest really is. ${ }^{89}$ For MacIntyre the idea of the 'ultimate end' of human reason is never closed but is an ongoing and necessarily incomplete exploration. $^{90}$

From this we can see that MacIntyre envisions the process of rational enquiry as dialectical (rather than circular) in nature. The pursuit of ultimate ends is necessary to animate a tradition - it connects a tradition to the past, carrying it forward in time and perpetuating the vitality of the social relationships and institutions on which it is based. Simultaneously, the pursuit of ultimate ends must take place through participation in a community. We receive what has come before, critically reflect on the meaning of those ideas within our current contexts and experiences, and through this process give shape to what will be passed on. In this dialectical process, reason can only be found and articulated with a view of the self (and society) as a unified whole, as within a narrative that connects all the parts of our lives. ${ }^{91}$ It cannot be divorced from social/political commitments, conceptual/linguistic inheritance, or the development of human virtues and excellences, as they exist in the context of shared practices.

With regard to the issues raised by $N S$, MacIntyre's theory would say that the resolution of conflicting rights is only possible when set within the context of a background that explains the unity between the rights at issue. To achieve this unity we must first have a conception of an ultimate good, which implies participation in a historically rooted community in pursuit of the ultimate good. Without an overarching concept of the ultimate good we are unable to understand fully the nature of the various goods of life (such as legal rights), including what is required to realize those goods. ${ }^{92}$

It is in looking for a conception of the good which will enable us to order other goods, for a conception of the good which will enable us to extend our understanding of the purpose and content of the virtues, for a conception of the good which will enable us to understand the place of integrity and constancy in life, that we initially define the kind of life which is a quest for the good. ${ }^{93}$

87 MacIntyre, Whose Justice?, supra note 76 at 93.

88 Ibid at $98-99$.

89 MacIntyre, After Virtue, supra note 71 at 219.

90 MacIntyre describes his project as a form of historicism that "...involves a form of fallibilism... [and] excludes all claims to absolute knowledge" ibid at 270. MacIntyre looks to Aquinas" theory as mode for the way that "...the ultimate end of human beings is outside and beyond this present life" (MacIntyre, Whose Justice?, supra note 76 at 192). And again: "The practical life, as Aquinas portrays it, is a life of enquiry by each of us into what our good is, and it is part of our present good so to enquire. The final discovery of what our good is will indeed reveal to us the inadequacy of all our earlier conceptions, an inadequacy strikingly expressed in Aquinas' verdict in his own work in the days immediately before his death. But at every stage in this practical enquiry we have a knowledge of our good adequate to guide us further..." (ibid at 193).

91 MacIntyre, After Virtue, supra note 71 at 205, 218.

92 Ibid at 201-203.

93 Ibid at 219. 
Without a concept of the ultimate good acting as a conceptual background we would be forced to rely on individual (or communal) preference in deciding cases involving a conflict between rights.

MacIntyre's theory of tradition provides a way of approaching conflicts between rights totally different from that taken in the NS case and the incommensurability thesis. Situating rational enquiry within tradition - participating in the pursuit of the ultimate human good that unifies all of our lives provides a background that is able to encompass even the most divergent rights and interests within a single discourse. Within this framework there is no need to seek 'neutrality', and neither does it merely assert a set of value commitments. Instead, it enables direct engagement with the many different substantive interests and perspectives that arise in the conflict between rights. This addresses the central weaknesses of the $N S$ analysis and the incommensurability thesis, but in so doing requires the adoption of a new, and relatively thick, philosophical foundation for legal discourse.

\section{Applying MacIntyre's Theory - Integrating Conflicting Goods and Multiple Voices}

What I want to draw out here is one of the natural results of MacIntyre's theory, which provides an important practical set of ideas for re-thinking our understanding of legal discourse. The point that I want to emphasize is that at the centre of MacIntyre's theory of rational enquiry is the engagement with and integration of diverse ideas and experiences. This gives context to why MacIntyre is so drawn to the philosophy of St. Thomas Aquinas, because his great achievement was to integrate the diverse voices of Augustinian theology and Aristotelian philosophy. ${ }^{94}$

For MacIntyre, traditions do not provide static definitions of meaning and truth developed in silos. Rather, they are constantly evolving and interacting with other ideas and conceptions of meaning and truth. For MacIntyre, a tradition evolves when it encounters something outside of its own conceptual framework - a set of ideas or an experience that it cannot account for from within its own resources. One of two things happens when a tradition encounters this. Normally, the participants within the tradition will develop solutions to these conceptual challenges by innovating with the resources of the tradition itself - pushing the meaning of those existing ideas to include the new phenomenon without disrupting the core identity of the tradition in the process. ${ }^{95}$ This results in the growth and expansion of the tradition, making it stronger. In extremely difficult situations this innovative process might fail, in which case the tradition enters into a moment of crisis, “... when by its own standards of progress it ceases to make progress...." A6 At this point a rival tradition might be able to provide an explanation for the crisis and its resolution, in which case the old tradition is either subsumed into the new tradition or it severs itself from the rational process and begins to disintegrate. ${ }^{97}$ In both cases, traditions are constantly confronting diverse voices and ideas. This experience is central to the life of a tradition as such - it represents the ongoing pursuit of a conception of the ultimate good, and the unification of human life.

This type of interaction with foreign concepts and other traditions, envisioned by MacIntyre as central to the process of rational enquiry, does not seem possible either within the balancing analysis provided by $N S$ or the incommensurability thesis. From what we have seen previously, the majority in

MacIntyre, Whose Justice?, supra note 76 at ch 10.

See ibid at 355-356.

Ibid at 361. The discussion of epistemological crises is described in detail from 361-365.

Ibid at 365 . 
$N S$ perceives its approach as standing above the fray, as neutral regarding values and the like, void of hierarchies of rights and values, purely formal and objective in balancing the harmful and beneficial effects of its decision. This view is incapable of engaging various voices and ideas in rational discussion because it denies the forum within which such a discussion is able to take place. The Court in NS denies the role of participation and conceptions of the ultimate good, focusing instead on an analysis that pushes various voices aside and devotes itself to arithmetic balancing. The philosophical grounding of individual preference identified by MacIntyre (and Glenn) seems to block the way.

Likewise, although the incommensurability thesis certainly draws on a set of ideas absent from the majority decision in $N S$, it still does not enable meaningful engagement with divergent points of view. Despite the attempts of the incommensurability thesis to incorporate a larger frame of social context in our understanding of the decision-making process, the analysis ends in an abstract choice for one understanding amongst many. The philosophical preference in the incommensurability thesis for individuality and particularity insulates it from external criticism - it can only be addressed within the frame of reference provided by the choice itself. The depth of analysis enabled by MacIntyre's theory appears to far outstrip that of the incommensurability thesis.

Standing somewhat alone is the approach taken by Justice LeBel in NS because he does not pretend to be above the discourse on values and relies rather heavily on his understanding of the Canadian legal tradition and its substantive value claims. Justice LeBel's understanding of tradition, legal discourse and rational enquiry is miles away from that proposed by MacIntyre. This is particularly clear in his view of the Canadian legal tradition as foundationally based on rules protecting open communication. ${ }^{98}$ An obvious response to this from MacIntyre's perspective would be that reason does not come through communicative openness alone - it might be necessary for rational dialogue, but is not itself sufficient. To focus the basis of legal discourse on the formal aspects of communication fails to critically reflect on how we conceptualize the necessary conditions of communication. This leaves unanswered some very important questions, such as why is the wearing of a niqab not counted as part of the testimony of the witness? Or, why does a niqab have to be seen as an inhibition to communication?

As I have argued throughout this paper, in order to critically reflect on these questions requires an idea of rational discourse that goes beyond the tools provided by the NS case and the incommensurability thesis. MacIntyre's theory of tradition-based rational enquiry provides one way to do this. But in order to employ MacIntyre's theory in the legal context it requires us to rather radically challenge the philosophical presumptions that underlie our current understanding of legal discourse. How that might look in practice is a question that will take considerable time and effort to adequately address. At very least, we can see from our brief discussion of MacIntyre's theory that in order to begin to answer these questions will require us to engage diverse views in a substantial and open way, as part of a single and unified discourse. This will substantially affect the way that we conceptualize the interaction between religious voices and non-religious voices within the framework of legal discourse. Most notably, it is not to say that one must subsume or bow to the other; rather, that all of these voices participate together in the pursuit of the ultimate human good.

98 See $N S$, supra note 1 at paras 70-78. 


\section{CONCLUSION}

The NS case opens a very interesting and compelling conversation regarding the nature of legal discourse and its relationship with diverse viewpoints. The conflict between rights in the case draws our attention to the background against which the meanings of those rights are understood. This leads us fairly quickly to consider the nature and impact of the philosophical presumptions underlying the legal analysis, and all of the complexities that go along with that. In $N S$, we are forced to confront the fact that the resolution of conflicting rights is really not about the rights at all, but about the vast set of ideas that are alive and moving under the surface of the legal analysis.

Having opened up this path of enquiry, I do not propose a nice answer or conclusion that will close it again. MacIntyre's theory of tradition-based rational enquiry certainly contributes to opening things further rather than closing them off. I am not ultimately concerned whether or not MacIntyre's theory is able to provide the answers to the questions now facing legal discourse and the adjudication of conflicting rights. I do contend, however, that he has put his finger on something important, and should not be silenced or ignored. MacIntyre provides a clear and compelling description and explanation for the difficulties identified with the $N S$ decision and with the incommensurability thesis. He also provides an alternative vision of rational discourse that challenges the way we are accustomed to think about legal discourse and its interaction with diverse points of view. Given the seeming insufficiency of the approaches taken in NS and the incommensurability thesis, MacIntyre's challenge should be welcomed even if it is unable to answer all of the questions we are left with. Indeed, MacIntyre's theory would be completely comfortable admitting that the questions cannot be fully answered - rational enquiry is a broad, dynamic and ongoing process. What is important is to engage the questions in such a way as to give us the best chance of success.

There are no simple or definitive solutions for the questions that have arisen throughout this paper. There are, however, a few general points that can be gleaned from the discussion that will help move us forward in a new and positive direction. First, we must identify the conceptual framework underlying the legal decision-making process, and its connection to historical context and the other modes of human and social experience. Secondly, we must allow our understanding of this framework to be open to criticism and challenge from both within and outside of its natural boundaries. We must be willing to acknowledge that the framework is always limited in some way and in constant need of adaptation and revision. Thirdly, ideas that come from a framework foreign to our tradition of law must be engaged seriously, as potentially having insight into the nature of the conflict and its resolution. To close off the discussion to ideas that do not already fit within our current framework undermines the value of the discussion (and our tradition) as a whole. This means that legal discourse should remain open to forms of discourse that are alien (or even opposed) to the framework of our legal tradition, and pursue forms of enquiry supportive of such openness.

As MacIntyre's theory demonstrates, ideas derived from religious discourse might be able to provide a unique perspective on legal issues that is immensely helpful - religious voices should not be prima facie disregarded and should not be forced to adapt to a presumed set of discursive and philosophical ideals in order to speak within our legal discourse. Indeed, it is the very difference of religious ideas that holds some promise for improving legal discourse. In light of MacIntyre's theory, we are 
compelled to reconsider the role of religious ideas in the processes of legal analysis, to reconceptualise the terms of their interaction so as to join them in the pursuit of a common end.

In conclusion, I would suggest that the apparent unwillingness of the Court in the $N S$ case to engage the questions discussed in this paper warrants serious concern. This resistance breeds a self-enclosed discourse laden with clearly identifiable predispositions as well as conceptual and structural analytic limitations. The voices of religion are muted within the legal discourse; religious ideas and interests are augmented to fit the framework of the court. Although its full implications are not readily available, my reflections on the $N S$ case, the incommensurability thesis and the theory of Alasdair MacIntyre provide a useful set of ideas to help recast the way we conceptualize legal discourse and the interactions it involves between religious and non-religious voices. Moreover, we are now in a position to explore new paths for investigating the pervasiveness of the framework underlying the NS case and to imagine better ways to integrate religious and legal discourses - to reconcile the distance often presumed to persist between what we see and what we think is behind the veil. 